\title{
Praworządny jak Tatarzyn? Stosunki prawne w Chanacie Krymskim na podstawie miejscowych ksiąg sądowych z XVII wieku
}

Poseł na Krym w latach czterdziestych XVI wieku Wencław Mikołajewicz z Mejszagoły, lepiej znany jako Michalon Litwin, pozostawił jeden z najstarszych opisów Chanatu Krymskiego ${ }^{1}$. Przedstawił go jako państwo idealnie sprawiedliwe. Litwina zachwycał chyba każdy z aspektów krymskiego systemu sprawiedliwości. Chwalił ogół mieszkańców za uczciwość, bo - jak pisał - ,rzadko spotka się u nich marnotrawcę jak umierającego z głodu, żebraka, oszusta, człowieka zachłannego na cudze, pieniacza, niesprawiedliwego sędziego, fałszywego świadka, krzywoprzysiężcę, złodzieja czy rozbójnika". Jego uznanie wzbudzali sędziowie, których celem była służba bliźniemu, a nie wzbogacenie się. Ponadto zachwycał się prostotą i szybkością postępowania procesowego i egzekucyjnego, które były pozbawione kruczków prawnych. Idea równości wszystkich wobec prawa także spotkała się z przychylną oceną posła ${ }^{2}$. Słowem, autor stawiał Tatarów, tych „bezbożnych bałwochwalców", za wzór obywatelom Wielkiego Księstwa Litewskiego, a niedoskonałym prawom obowiązującym we własnej ojczyźnie przeciwstawiał świetnie sprawdzające się rozwiązania tatarskie. Należy zauważyć, że Michalon nie był jedynym chrześcijaninem wychwalającym praworządność Tatarów Krymskich. Czterdzieści lat po nim zachwycał się tą cechą chańskich poddanych poseł Rzeczypospolitej Marcin Broniewski ${ }^{3}$, a w drugiej połowie XVIII wieku na chańską sprawiedliwość zwrócił uwagę francuski konsul Baron de Tott ${ }^{4}$.

${ }^{1}$ Zob. J. Ochmański, Michalon Litwin i jego traktat „, O zwyczajach Tatarów, Litwinów i Moskwicinów z połowy XVI wieku", [w:] idem, Dawna Litwa, Olsztyn 1986, s. 134-157.

${ }^{2}$ Michalonis Lituani, De moribus Tartarorum, Litvanorum et Moschorum, fragmina decem, Basileae 1615, s. 19-21.

${ }^{3}$ M. Broniewski, Tartariae Descriptio, Coloniae 1595, s. 16.

${ }^{4}$ F. de Tott, Memories of the Baron de Tott, on the Turks and the Tartars, London 1785, t. 2 , s. 381-382. 
Rodzi się pytanie: czy autorzy dobrze poznali i później możliwie wiernie opisali krymską rzeczywistość, czy też wybrali jej umoralniające aspekty? Odpowiedzi na to pytanie dostarcza lektura krymskich ksiąg sądowych. Bogaty materiał w nich zawarty, uzupełniony o wiadomości zaczerpnięte $\mathrm{z}$ innych źródeł tatarskich, osmańskich i europejskich, pozwala poznać wiele aspektów krymskiego systemu prawnego. Jego opis stanowi cel niniejszego artykułu. Ponieważ zarówno ustrój Chanatu, jak i podstawowe zagadnienia związane $z$ jego prawem nie są zbyt dobrze w Polsce znane - warto zarysować tło.

Najważniejszą część artykułu stanowi ustalenie: kto, przeciw komu i w jakich sprawach występował przed danym typem sądów? Szczegółowa analiza zostanie przedstawiona na przykładzie materiałów z ksiąg sądowych spisanych za czasów panowania chana Murata Gireja (1678-1683) ${ }^{5}$. Sądownictwo za jego rządów, przypadających na przełomowy okres w dziejach Chanatu, łączy - o ile można sądzić - cechy wcześniejsze z tymi charakterystycznymi już dla wieku XVIII. Informacje zawarte w księgach rzucają nowe światło na kwestie sprawnego funkcjonowania i bezstronności krymskiego sądownictwa. Przybliżają nas do odpowiedzi na pytanie: czy istotnie krymska Temida była ślepa na status społeczny i majątkowy podsądnych?

I. Kilka uwag o ustroju i prawie Chanatu Krymskiego. Chanat Krymski powstał z rozpadu Złotej Ordy w połowie XV wieku. Jego instytucje państwowe i prawo oparto na wzorcach zarówno mongolskich, jak i islamsko-osmańskich, tworząc system niezwykle ciekawy i oryginalny. Najwyższe godności w państwie zarezerwowano dla członków dynastii Girejów, wywodzącej się od Czyngis-chana. Spośród nich wybierano zarówno samego chana, jak i katge - jego pierwszego następcę, a w późniejszym okresie innych ważnych dygnitarzy, czyli nureddina - drugiego następcę chana oraz seraskierów - namiestników chańskich przy ordach nogajskich. Chan był symbolem krymskiej państwowości i dzierżył najwyższą władzę w państwie. Wydaje się jednak, że zachodziły istotne różnice $\mathrm{w}$ realnym zakresie jego władzy na poszczególnych terytoriach Chanatu. Pełnym autorytetem cieszył się w swojej domenie, a ograniczonym - na ziemiach zarządzanych przez katgę i naczelników wielkich rodów (karaczy begowie). Wynikało to zapewne z tradycji mongolskiej, która gwarantowała klanom dużą autonomię we władaniu ziemią. Wielu cha-

${ }^{5}$ Krymskie księgi sądowe, których kolekcja obejmuje 121 tomów, są obecnie przechowywane w Bibliotece Narodowej w Petersburgu (Otdel Rukopisev Rossiiskoi Natsionalnoi Biblioteki [później: ORRNB], Fond 917). Przed 1799 rokiem przekazał je władzom rosyjskim ostatni krymski sędzia najwyższy (kadiasker) Mehmed Aga. Do 1905 roku były przechowywane w Symferopolu, a następnie zostały przewiezione do Petersburga (O. Wasiliewa, Krymsko-tatarskije rukopisnyje materialy w otdele rukopisii, „Rossiiskaja Nationalnaja Biblioteka. Wostocznyj Sbornik” 5 (1993), s. 37-45). Z czasów panowania Murata Gireja zachowały się księgi kadiaskerskie z lat 1678-1681 (deftery numer 22, 23a i 23b), a także księga sądu prowincjonalnego z miasta Karasu z roku 1683 (defter numer 25). 
nów starało się rozszerzać swoje wpływy na terenach niewchodzących w skład ich domeny. W tym celu - między innymi - administrację centralną i prowincjonalną rozbudowywali o urzędników od siebie zależnych. Zmiany te często wzorowano na administracji Imperium Osmańskiego. Stąd też główne instytucje centralne chanatu stanowiły przykład połączenia tradycji mongolskiej i osmańskiej. Rada chańska (dywan), której przewodniczył chan, a w której zasiadali mianowani przez niego najwyżsi urzędnicy, przypominała radę sułtana osmańskiego. Nie była jednak jej lustrzanym odbiciem, ponieważ stale zasiadali w niej dygnitarze, których urzędy zakorzenione były w tradycji mongolskiej (katga, nureddin, karaczy begowie). Druga istotna instytucja centralna, czyli zgromadzenie szlachty krymskiej (kurultaj), wywodziła się już w pełni z tradycji mongolskich. Należy podkreślić, że w obu instytucjach chan, chociaż miał silną pozycję, musiał jednak liczyć się z prawami naczelników wielkich rodów. Wchodzili oni w skład rady, a jeden lub dwóch najważniejszych mieli prawo zwoływania kurultaju. Mogli oni skorzystać z tej możliwości - na przykład - w celu wypowiedzenia posłuszeństwa chanowi lub odmówienia wykonania jego rozkazów. Znaczenie i wpływ wielkich rodów sięgał czasów Złotej Ordy. Stabilną sytuację materialną zapewniały im dochody z bejlików, czyli niepodzielnych dóbr ziemskich będących własnością rodów i zarządzanych przez ich naczelników - begów. Znaczenie polityczne, obok wspomnianego udziału w radzie i kurultaju, gwarantowało im prawo dowodzenia podczas wypraw oddziałami złożonymi z członków rodów i ich klientów. Zakres jurysdykcji chańskiej w odniesieniu do bejlików i ich mieszkańców stanowi cenną wskazówkę dotyczącą ograniczeń władzy chana, a także jego stosunków w wasalami. Powstaje pytanie: jak zorganizowane było sądownictwo na terenach bejlików i w jakim stopniu podlegało ono chanowi i opierało się na jego autorytecie? Kto, w jakich sprawach i zgodnie z jakimi normami prawnymi odpowiadał przed sądami władcy, a kiedy podsądni szukali sprawiedliwości przed alternatywnymi forami, takimi jak rada starszych rodu?

Zgodnie $\mathrm{z}$ islamem, podstawowym obowiązkiem władcy muzułmańskiego jest stanie na straży przestrzegania prawa i zapewnienie poddanym dostępu do sprawiedliwych sądów. W epoce nowożytnej władcy muzułmańscy, w tym chan krymski, przedstawiali się jako obrońcy świętego prawa - szaria$t u$. Należy jednak zauważyć, że szczegółowe normy stosowane w prawie muzułmańskim zależały w pewnej mierze od przyjętej szkoły interpretacji prawa. W islamie sunnickim w epoce nowożytnej istniały cztery główne szkoły prawa. W Chanacie, podobnie jak w Imperium Osmańskim, władca wybrał za czołową jedną z nich - szkołę hanaficką. Spośród jej członków wybierano najwyższych sędziów oraz muftich ${ }^{6}$, a także sam władca, przynajmniej ofi-

${ }^{6}$ Tytuł muftiego nosił uczony w prawie muzułmańskim, który mógł wydawać niewiążące opinie prawne tzw. fetwy. W Imperium Osmańskim i w Chanacie istniał urząd najwyższego muftiego, który rezydował w stolicy państwa i pełnił istotną rolę zarówno polityczną, jak i religijną. 
cjalnie, postępował zgodnie z jej zaleceniami. Niemniej - jego muzułmańscy poddani mogli należeć do którejś z pozostałych trzech szkół.

Nie można także ignorować faktu, że w wielu państwach muzułmańskich szariat, przynajmniej od początku XIII wieku, był uzupełniany przez prawo zwyczajowe oraz prawo stanowione przez władców. Było to konieczne ze względu na coraz bardziej skomplikowane struktury administracyjne. Szariat nie rozwiązywał bowiem wielu kwestii związanych z tak istotnymi dziedzinami jak prawo karne i sprawy podatkowe. W konsekwencji - w nowożytnych państwach muzułmańskich, takich jak Chanat czy Imperium Osmańskie, normy wywodzące się z szariatu stanowiły dość giętką ramę, którą modyfikowano i uzupełniano różnymi regulacjami odpowiadającymi nie tylko dawnym zwyczajowym prawom ludności, lecz i współczesnym potrzebom państwa. Niestety w przypadku Chanatu nie dysponujemy spisanymi kodeksami prawa stanowionego, takimi jak na przykład osmańskie kanunname. O legislacyjnej działalności krymskich władców świadczą jedynie rozkazy ich samych i ich kałgów (jarłyki) oraz nieliczne wzmianki w źródłach narracyjnych. Z tych samych źródeł można czerpać informacje o prawie zwyczajowym w Chanacie. Określano je terminami „stare prawo” (kanun-i kadim) czy też „,czyngisydzkie prawo" (kanun-i cingiziye). To ostatnie określenie, jak i treść tych zwyczajów wskazuje na ich mongolskie pochodzenie ${ }^{7}$.

W Chanacie władca pozostawał najwyższym sędzią rozstrzygającym spory na forum swojej rady ${ }^{8}$ W jej skład, obok wymienionych już członków,

${ }^{7}$ Do lat siedemdziesiątych XX wieku obowiązywał pogląd, że Czyngis-chan pozostawił spisany kodeks praw zwany jasa. Miał go promulgować na kurultaju w 1205 lub 1206 roku. Uważano, że odwołania do prawa czyngisydzkiego czy też starego prawa w państwach poczyngisydzkich nawiązują właśnie do tego spisanego kodeksu. Niektórych badaczy zastanawiał co prawda fakt, że do naszych czasów nie dotrwała żadna kopia kodeksu, ale przywiązanie do idei spisanej jasy było tak silne, że w najróżniejszy sposób tłumaczyli ten brak, patrz: François Petis de la Croix, The History of Genghizcan the Great, London 1722, G. Vernadsky, The Scope and Contents of Chingis Khan's Yasa, „Harvard Journal of Asiatic Studies” 3 (1938), s. 337-360, V. Riazanovsky, Fundamental Principles of Mongol Law, Bloomington 1965, s. 83-91, D. Ayalon, The Great Yasa of Chingiz Khan: a reexamination, „Studia Islamica” 33 (1971), s. 97-140; 34 (1971), s. 151-180; 36 (1972), s. 112-158; 38 (1973), s. 107-156. Dopiero w latach osiemdziesiątych ubiegłego stulecia David Morgan odważył się zakwestionować istnienie kodeksu spisanego na rozkaz Czyngis-chana. Studia tego badacza, jak i późniejsze prace Denise Aigle, zawierają przekonującą argumentację za zmianą definicji terminu jasa. W ich ujęciu oznacza on niepisany zbiór praw stosowany przez Mongołów, a także - do pewnego stopnia - w państwach poczyngisydzkich. Tak rozumiana jasa to zbiór praw zwyczajowych, które istniały przed Czyngis-chanem, a ewoluowały zarówno za jego życia jak i w państwach-sukcesorach jego imperium, patrz: D.O. Morgan, The Great Yasa of Chingiz Khan and Mongol Law in the Ilkhanate, „Bulletin of the School of Oriental and African Studies" 49 (1986), s. 168; D. Aigle, Le grand jasaq de Gengis-khan, l'empire, la culture mongole et la shari “a, „Journal of the Economic and Social History of the Orient” 47 (2004), s. 31-79.

${ }^{8} \mathrm{Z}$ czasów panowania Murata Gireja zachowały się dwadzieścia dwa wpisy dotyczące spraw rozstrzyganych przez sąd rady, zob. N. Królikowska, Law and Division of Power in the Crimean Khanate. A Study on the Reign of Murad Giray (1678-1683), praca doktorska obroniona na Uniwersytecie Warszawskim w 2010 r., s. 98-107. 
wchodził najwyższy sędzia noszący tytuł kadiaskera. Brał on udział nie tylko w rozstrzyganiu spraw toczonych przed radą, ale także przewodniczył własnemu sądowi, przed który wnosili sprawy najróżniejsi mieszkańcy Chanatu. Mogli oni także zwracać się do prowincjonalnych sędziów (kadi), którzy byli najważniejszymi urzędnikami w okręgach sądowo-administracyjnych (kazy), na które podzielony był Chanat. W ich obrębie kadiowie łączyli funkcje sądownicze $\mathrm{z}$ administracyjnymi, takimi jak: nadzorowanie poboru podatków i funkcjonowania fundacji religijnych, kontrola wprowadzania w życie chańskich rozkazów przysyłanych do danego okręgu sądowego, czy pomoc w organizacji kampanii wojennych ${ }^{9}$. W wypełnianiu obowiązków pomagało im kilku pomniejszych urzędników. Byli to m.in. naibowie - podsędkowie, katibowie - pisarze oraz muhzirowie - woźni. Wydaje się, że poziom specjalizacji i liczba urzędników pełniących daną funkcję zależała od wielkości okręgu. W mniejszych okręgach jeden urzędnik mógł pełnić równocześnie kilka funkcji, np. naiba i katiba. Istnieją przesłanki, że w dużych miastach Chanatu, Bachczysaraju i Karasu, w egzekucji wyroków sędziom pomagały także stacjonujące tam oddziały wojsk chańskich.

Pozostaje kwestią nierozstrzygniętą, w jakim stopniu chan mógł wpływać na obsadzanie stanowisk sędziów na terenach okręgów, w których leżały terytoria wielkich rodów oraz domena katgi. W przypadku tych pierwszych - wydaje się na podstawie szczegółowej analizy różnych typów źródeł, że istniał kompromis pomiędzy chanem a miejscowym begiem. Do naczelnika rodu należało przedstawienie kandydata, którego akceptował chan. Pozostaje kwestią otwartą: jakie kompetencje administracyjne miał tak mianowany sędzia na terytoriach bejliku i na pozostałym terenie okręgu, zależnym bezpośrednio od chana? W przypadku domeny kałgi źródła narracyjne jasno stwierdzają, że to on sam mianował sędziów. Chan zachował jednak kontrolę nad sądownictwem na tym terytorium, ponieważ każdy mieszkaniec mógł przenieść sprawę do sądu rady chańskiej, ponadto zaś - chan miał wyłączne prawo do wydawania wyroków śmierci.

Podczas codziennego funkcjonowania sądów powstawały księgi sądowe (sidżille), które ukazują sądowniczą i administracyjną działalność sędziów oraz podległych im urzędników, a także są niezwykle cennym źródłem do badania historii społeczno-ekonomicznej północnego wybrzeża Morza Czarnego ${ }^{10}$. Dla

${ }^{9}$ Zob. ORRNB, Fond 917, defter 1/12b/1; defter 25/115a/1, 25/115a/2, 25/115a/6; 25/117b/3.

${ }^{10}$ Krymskie księgi sądowe wykorzystywali jako źródło już w XIX wieku badacze pracujący w Imperium Rosyjskim. Niezwykle cenne studia opublikował wówczas Fiodor Laškov, patrz: idem, Istoričeskij očerk krymsko-tatarskogo zemlevladenija, część 1 - „Izvestija Tavričeskoj Učenoj Arhivnoj Komissii” [dalej ITUAK] 22 (1895), s. 35-81; część 2 - ITUAK 23 (1896), s. 71-117; część 3 - ITUAK 24 (1896), s. 35-71; part 4 - ITUAK 25 (1897), s. 29-88. W tym samym okresie wydano także pierwsze thumaczenia wybranych wpisów, patrz: Sbornik dokumentov po istorii krymsko-tatarskogo zemlevladenija, wyd. F. Laškov, część 1 - ITUAK 22 (1895), s. 82-115; część 2 - ITUAK 23 (1896), s. 118-129; część 3 - ITUAK 24 (1896), s. 72-137; część 4 - ITUAK 25 (1897), s. 89-154; 
Chanatu zachowało się sto dwadzieścia jeden ksiąg z lat 1608-1783. Zawierają one materiały powstałe w sądzie rady chańskiej, sądzie kadiaskera oraz sądach prowincjonalnych w miastach Bachczysaraj i Karasu. Najprawdopodobniej jedna z ksiąg dotyczy miasta Gözleve - najważniejszego portu Chanatu. Niestety dla żadnego sądu nie zachował się komplet ksiąg. Zachowane księgi często dzielą między sobą kilku-, a nawet kilkunastoletnie przerwy.

Zasadniczo w krymskich księgach sądowych znajdują się dwa typy dokumentów. Pierwszą, stanowczo mniej liczną grupę, stanowią dokumenty przesyłane sędziom przez chanów oraz kałgów (w sumie: siedemdziesiąt dziewięć). W krymskich księgach sądowych znajduje się także piętnaście pism sułtanów osmańskich i ich urzędników, dotyczących spraw Chanatu i jego mieszkańców. Drugą grupę stanowią zapisy spraw rozstrzyganych lub rejestrowanych w sądzie. Należy podkreślić, że sprawy wpisywano do ksiąg sądowych w języku osmańskim, w sposób zgodny z formułami używanymi także w Imperium Osmańskim. Standardowy wpis do księgi sądowej rozpoczynał się od informacji o stronach umowy bądź sporu. Formuły początkowe zawierały informacje o imionach, tytułach stron sporu. Często te części wpisów zawierały także informacje o ojcach osób występujących w sprawach. $\mathrm{Na}$

część 5 - ITUAK 26 (1897), s. 24-154; M. Biarslanov, Wypiski iz kadiaskerskago sakka (knigi) 1017-1022 g. hidžry (1607/8-1613 g. Hr. let.) hraniaščiagosja v arhive Tavričeskago gubernskago pravlenija, ITUAK 9 (1890), s. 68-69. W okresie istnienia ZSRR uwarunkowania polityczne sprawiły, że badań nad krymskimi księgami sądowymi zaprzestano. Dopiero otwarcie archiwów i bibliotek rosyjskich w latach 90-tych ubiegłego stulecia oraz odnalezienie faksymile połowy kolekcji w Symferopolu przez Hakana Kırımlı umożliwiło dalszą pracę nad analizą tych źródeł, patrz: H. İnalcık, Kırım Hanlı̆̆ Sicilleri Bulundu [Krymskie księgi sadowe odnalezione], „Belleten” 60: 227 (1996), s. 170-189. W ciągu ostatnich kilkunastu lat opublikowano m.in. następujące studia na podstawie materiałów z ksiąg sądowych: R. Çiğdem, Crimes Threatening Bodily Integrity (Assault and Battery): A Legal Analysis of Four Cases From the Judicial Registers of the Bakchisaray/Crimea Law Court, „Ankara Üniversitesi Hukuk Fakültesi Dergisi” 54: 1 (2005), s. 61-71; idem, Khul or Dissolution of Marriage by a Woman: A Historical Background and Two Cases From the Bakchisaray/ Crimea Court, „Dokuz Eylül Üniversitesi İlahiyat Fakültesi Dergisi” 21 (2005), s. 95-115; idem, The Judicial Registers of the Bakchisaray/Crimea Law Court: A Study of Murder Crimes, „Hamdard Islamicus" 28: 4 (2005), s. 41-53; M. Kravets, From Nomad's Tent to Garden Palace: Evolution of a Chinggisid Household in the Crimea, Toronto Studies in Central and Inner Asia 7 (2005), s. 47-60; eadem, Blacks Beyond the Black Sea: Eunuchs in the Crimean Khanate, w: Slavery, Islam and Diaspora, wyd. B.A. Mirzai, I.M. Montana, P.E. Lovejoy, New York 2009, s. 21-36; N. Królikowska, Ród Jaszławskich przed sądem chana Murada Gireja. Przyczynek do dziejów mirzów krymskich, w: Od Attaju po Syberię, eadem, wyd. E. Siemieniec-Gołaś, J. Georgiewa-Okoń, Kraków 2010, s. 115-120; Crimean Crime Stories. Homicide and Bodily Harm Cases During the Reign of Murad Giray (1678-1683), eadem, Crimean Crime Stories. Homicide and Bodily Harm Cases During the Reign of Murad Giray (1678-1683), w: The Early Modern Crimean Khanate Between East and West, wyd. D. Klein, München 2012, s. 109-123; Z. Özdem, Kırım Karasubazar'da SosyalEkonomik Hayat. 17. Yüzyll Sonlarından 18. Yüzyll Ortalarına Kadar [Życie społeczne i ekonomiczne Karasu na Krymie: od końca XVII do połowy XVIII wieku], Ankara 2010; Ahmet Turan, Sudebnye rejestry krymskovo hanstva (posle ih obnaruženija), „Kultura narodov pričernomorja” 30 (2002), s. 90-93; idem, Kırım Hanlığı Kadı Sicilleri Hakkında Notlar [Uwagi nad księgami sądowymi Chanatu Krymskiego], „Türk Kültürü İncelemeleri Dergisi” 9 (2003), s. 1-16. 
ogół wskazywały także na religię osób pojawiających się w sądzie oraz na ich pochodzenie społeczne i miejsce zamieszkania. Zawód rzadko stanowił element tego opisu. Po identyfikacji stron następował zapis kontraktu bądź sporu. W przypadku tego drugiego - rozpoczynał się wystąpieniem oskarżyciela w sprawach karnych lub powoda w cywilnych, po którym następowała odpowiedź oskarżonego albo pozwanego. Dowody przytoczone przez obie strony stanowiły kolejną część wpisu. Niestety w większości spraw próżno szukać wyroku sędziego, ponieważ najczęściej wpis kończyła zwyczajowa formuła zapewniająca, że wydano wyrok zgodnie z prawem. Bardzo rzadko pisarz podawał, w jaki dokładnie sposób sędzia rozwiązał spór lub jaka kara czekała przestępcę. W końcowej części wpisu znajdowała się jeszcze data oraz lista „świadków sądu” (şuhudu l-hal), którzy przysłuchiwali się sprawie lub byli świadkami wpisywania kontraktu.

„Świadkowie sądu” pełnili bardzo ważną rolę w sądach w Chanacie, a także w Imperium Osmańskim. Badacze pracujący na osmańskich księgach sądowych zwrócili uwagę, że ich rola polegała nie tylko na poświadczaniu, iż wpis odpowiada rzeczywistemu przebiegowi sprawy, ale także na obserwacji pracy sądu ${ }^{11}$. Leslie Peirce następująco opisała ich rolę:

„their function was to act as a check on the correctness of legal procedures observed in the case as whole and to serve as repository of communal memory of the incident at issue [ich rolą było sprawdzenie czy zastosowano odpowiednie procedury w sprawie. Ponadto służyli jako repozytariusze zbiorowej pamięci wspólnoty o danej sprawie]"12.

Kwestia rekrutacji ,świadków sądu” w dalszym ciągu nie jest jednoznacznie wyjaśniona. Nie ulega wątpliwości, że nie stanowili oni łatwo definiowalnej grupy, na przykład: najbogatszych czy też najlepiej wykształconych członków lokalnej społeczności. Wydaje się, że między „świadkami sądu” znajdowały się zarówno osoby przysłuchujące się wszystkim sprawom rozstrzyganym $\mathrm{w}$ danym dniu czy tygodniu, jak i ludzie zainteresowane tylko jedną sprawą. Często ma się wrażenie, że „świadek sądu” nie pojawiał się przypadkowo w pewnej sprawie - np. oficer janczarski w procesie janczara oskażonego o zbrojną napaść ${ }^{13}$. Niemniej, w większości przypadków trudno jednoznacznie stwierdzić, dlaczego dany świadek przysłuchiwał się konkretnej sprawie. Badacze różnią się w swoich opiniach na temat: czy specjalnie wybierano świadków sądu do danych spraw? Podczas gdy Ronald Jennings i Karen Barkey widzieli świadków jako osoby neutralne i niezwiązane ze

${ }^{11}$ R. Jennings, Limitations of the Judicial Power of the Kadi in $17^{\text {th }}$ Century Kayseri, ,Studia Islamica" 49 (1979), s. 151-184.

${ }^{12}$ L. Peirce, Morality Tales: Law and Gender in the Ottoman Court of Aintab, London 2003, s. 97.

${ }^{13}$ ORRNB, defter 23b/25b/1. 
sprawą, Leslie Peirce i Boğaç Ergene sugerowali, że obecność pewnych grup osób w określonych sprawach nie była czystym przypadkiem. Niemniej, dotychczas nikomu nie udało się udowodnić, że konkretny zestaw świadków sądu został specjalnie wybrany, by przysłuchiwać się określonej sprawie ${ }^{14}$. Nie ulega jednak wątpliwości, że wielu spośród „świadków sądu” nosiło tytuły wskazujące na ich wykształcenie religijne, prawne bądź pracę w administracji, co sugeruje, że ich głównym zadaniem była obserwacja prawidłowego funkcjonowanie wymiaru sprawiedliwości.

Kluczowym problemem jest kwestia, czy istniały zależności pomiędzy sposobem i możliwościami korzystania z sądownictwa chańskiego a statusem jednostki? Należy więc pokazać, w jaki sposób był on opisany w formułach używanych w księgach sądowych.

Do tej pory historycy nie wypracowali jasnych kryteriów opisu podziałów społeczeństwa Chanatu. Co więcej, nie do końca oczywisty jest zbiór kryteriów, według których sami Tatarzy określali status społeczny jednostki. Analiza ksiąg sądowych wskazuje, że lokalni urzędnicy definiowali ten status, używając osmańskich terminów uzupełnionych o te typowe dla Chanatu. W przypadku mężczyzn księgi sądowe zazwyczaj podają ich imiona i tytuły, a także imiona i tytuły ich ojców. Kobiety były opisane poprzez swoje imię, a rzadziej także tytuł oraz imię i tytuł ojca. Czasem podawano także dane dotyczące męża kobiety.

Zgodnie z prawem muzułmańskim podstawowym kryterium podziału społeczeństwa jest przynależność do islamu. Nie budzi więc zdziwienia, że W większości przypadków księgi umożliwiają stwierdzenie, czy dana osoba jest muzułmaninem. W przypadku nie-muzułmanów często możliwe jest stwierdzenie ich wyznania. Właściwie wyłącznie w przypadku duchownych można uzyskać informacje o statusie społecznym. W pozostałych przypadkach zawód i bogactwo pozostają jedynymi informacjami, na których można próbować rekonstruować miejsce jednostki w społeczności.

Tytuły - lub ich brak - w odniesieniu do muzułmanów pozwalają podzielić osoby pojawiające się w sądzie na pięć grup:

1. członkowie dynastii Girejów (chan, sułtan, hani);

2. szlachta (bek, mirza, emeldesz, ulan);

3. członkowie elity wojskowej i administracyjnej (aga, bek, besze);

4. członkowie elity religijnej (czelebi, efendi, chodża, szejch, dede, sejjid);

5. zwykli muzułmanie (brak tytułów innych niż hadżi/hadżije dla mężczyzn/kobiet, którzy odbyli pielgrzymkę do Mekki).

Zaproponowany podział niewątpliwie ma pewne niedoskonałości. Po pierwsze: często niejasne jest, czy dana osoba winna być zakwalifikowana jako szlachta, czy też jako członek elity wojskowo-administracyjnej lub reli-

${ }^{14}$ L. Peirce, Morality Tales, s. 97. 
gijnej. Trudności wynikają z faktu, że część szlachty krymskiej robiła karierę w administracji chańskiej lub była członkiem elit religijnych. W tych przypadkach zdecydowano się na zakwalifikowanie jednostek raczej zgodnie z ich drogą kariery niż urodzeniem. Po drugie: trudności sprawia identyfikacja statusu społecznego kobiet. Najlepiej oddaje go status społeczny męża, jeżeli tylko został zapisany w księgach. W przypadku braku tych danych, kobieta została przypisana do grupy ojca. Takie rozwiązanie ma jednak pewne wady. Podczas gdy bardzo rzadko muzułmanka wychodziła za mąż za mężczyznę o niższym statusie społecznym, to muzułmanin mógł ożenić się z każdą kobietą, nawet wyzwoloną niewolnicą. Nie można wykluczyć, że status kobiety z okresu przed małżeństwem miał wpływ na sposób, w jaki korzystała ona z sądów. Niemniej, ponieważ celem niniejszej pracy nie są gender studies, postanowiono traktować jednakowo wszystkie zamężne muzułmanki, bez względu na ich pochodzenie. Jedyny wyjątek zrobiono wobec kobiet z rodziny panującej, które nawet po zamążpójściu zostały zakwalifikowane do członków rodu Girejów. Po trzecie: powyższy podział nie oddaje różnic ekonomicznych pomiędzy członkami jednej grupy społecznej ${ }^{15}$.

Należy zwrócić uwagę na jeszcze jeden istotny element opisu jednostki we wpisach sądowych - miejsce zamieszkania. Jest to niezwykle ważna informacja, która umożliwia zbadanie właściwości miejscowej poszczególnych sądów, a przez to przybliża do odpowiedzi na pytanie o zakres władzy chana na poszczególnych terenach, np. w bejlikach wielkich rodów czy też domenie katgi. Jeżeli we wpisach znajduje się informacja o miejscu zamieszkania, to najczęściej ogranicza się ona do nazwy wioski lub dzielnicy miasta, z której pochodziły strony w sprawie. Czasami dodawano, w jakim okręgu sądowym leży wymieniona miejscowość. W znacznym odsetku spraw brakuje tej wiadomości, co znacznie utrudnia lokalizację małych miejscowości ze względu na brak odpowiedniej wczesnonowożytnej dokumentacji oraz ogromne, wymuszone ruchy ludności i związane z nimi zmiany nazw własnych na Krymie w ostatnich dwustu pięćdziesięciu latach ${ }^{16}$.

Podsumowując: księgi sądowe dostarczają cennych danych, które przybliżają nas do odpowiedzi na pytanie: kto i w jaki sposób szukał chańskiej sprawiedliwości?

${ }^{15}$ Warto zauważyć, że zaproponowany powyżej podział nie jest jedynym możliwym do zastosowania w przypadku Chanatu. Niezwykle ciekawym pytaniem, wykraczającym poza ramy tego artykułu, jest: czy można zastosować w przypadku Chanatu podstawowy podział społeczeństwa znany z Imperium Osmańskiego, na jednostki płacące podatki $\mathrm{i}$ te $\mathrm{z}$ nich zwolnione $\mathrm{w}$ zamian za służbę władcy. Ten podział miał korzenie w prawie stanowionym przez sułtana osmańskiego. Źródła dotyczące Chanatu wskazują, że przynajmniej mieszkańców domeny chańskiej można próbować dzielić według tego kryterium.

${ }^{16}$ H. Jankowski, A Historical-Etymological Dictionary of Pre-Russian Habitation Names of the Crimea, Leiden-Boston 2006; B.G. Williams, The Crimean Tatars. The Diaspora Experience and the Forging of a Nation, Leiden-Boston 2001, s. 404. 


\section{Klienci sądów chańskich - analiza ich statusu społecznego, płci i miejsca zamieszkania.}

1. Status społeczny. Szczegółowa analiza wpisów z okresu panowania Murata Gireja wskazuje, że klientami sądów chańskich byli przedstawiciele wszystkich wyżej wymienionych grup społecznych, zarówno muzułmanie jak i nie-muzułmanie. Ponadto stronami w sprawach bywali także niewolnicy oraz wspólnoty wiejskie i fundacje religijne (wakfy). Warto zwrócić uwagę na interesujące różnice $\mathrm{w}$ sposobie korzystania z różnych typów sądów przez członków poszczególnych grup. Poniższe tabele zawierają dane odnoszące się do sądu kadiaskera (dane z lat 1678-1681) i sądu prowincjonalnego w Karasu (dane z roku 1683).

Tabela 1. Pochodzenie społeczne stron w sądzie kadiaskerskim

\begin{tabular}{l|c|c|c}
\hline \multirow{2}{*}{ Pochodzenie społeczne } & \multicolumn{2}{|c|}{ Sprawy sporne (w \%) } & $\begin{array}{c}\text { Sprawy } \\
\text { niesporne (w \%) }\end{array}$ \\
\cline { 2 - 4 } & $\begin{array}{c}\text { Oskarżyciele/ } \\
\text { powodowie }\end{array}$ & $\begin{array}{c}\text { Oskarżeni/ } \\
\text { pozwani }\end{array}$ & \\
\hline Girejowie & 1,0 & 5,4 & 3,3 \\
\hline Szlachta & 6,6 & 8,9 & 13,0 \\
\hline $\begin{array}{l}\text { Członkowie elity wojskowej } \\
\text { i administracyjnej }\end{array}$ & 9,1 & 11,0 & 13,1 \\
\hline Członkowie elity religijnej & 13,1 & 15,1 & 18,2 \\
\hline Zwykli muzułmanie & 48,2 & 43,5 & 44,2 \\
\hline Nie-muzułmanie & 16,5 & 14,2 & 4,6 \\
\hline Niewolnicy & 2,1 & 0,3 & 0,4 \\
\hline Lokalne wspólnoty & 1,4 & 1,3 & 1,3 \\
\hline Fundacje religijne & 2,0 & 0,2 & 1,5 \\
\hline
\end{tabular}

Tabela 2. Pochodzenie społeczne stron w sądzie w Karasu

\begin{tabular}{l|c|c|c}
\hline \multirow{2}{*}{ Pochodzenie społeczne } & \multicolumn{2}{|c|}{ Sprawy sporne (w \%) } & \multirow{2}{*}{$\begin{array}{c}\text { Sprawy } \\
\text { niesporne } \\
\text { (w \%) }\end{array}$} \\
\cline { 2 - 3 } & $\begin{array}{c}\text { Oskarżyciele/ } \\
\text { powodowie }\end{array}$ & $\begin{array}{c}\text { Oskarżeni/ } \\
\text { pozwani }\end{array}$ & 1,6 \\
\hline Szlachta & 0,6 & 0,6 & 7,2 \\
\hline $\begin{array}{l}\text { Członkowie elity wojskowej } \\
\text { i administracyjnej }\end{array}$ & 6,3 & 4,5 & 6,0 \\
\hline Członkowie elity religijnej & 6,3 & 3,2 & 45,2 \\
\hline Zwykli muzułmanie & 44,0 & 48,0 & 38,8 \\
\hline Nie-muzułmanie & 40,1 & 43,7 & 0,4 \\
\hline Niewolnicy & 0,0 & 0,0 & 0,0 \\
\hline Lokalne wspólnoty & 0,7 & 0,0 & 1,8 \\
\hline Fundacje religijne & 2,0 & 0,0 & \\
\hline
\end{tabular}


Analiza powyższych danych pokazuje, jak różne grupy społeczne korzystały z obu typów sądów. W sądzie kadiaskera zwykli muzułmanie i nie-muzułmanie stanowili około $60 \%$ klientów sądu zarówno w kwestiach spornych jak i w sprawach niespornych, takich jak kontrakty zawierane zgodnie przez strony, wpisy testamentów czy wyzwolenia niewolników. Członkowie grup elitarnych - szlachta, wojsko, urzędnicy, osoby pełniące funkcje religijne byli zaangażowani w około 35\% spraw. Fundacje religijne reprezentowane przez swoich zarządców także stanowiły strony w sprawach. Podobnie przed sądem pojawiały się lokalne wspólnoty mieszkańców jednej wioski lub jednej dzielnicy miasta (mahalle) w sprawach dotyczących ich wspólnych interesów. Zasadniczo występowały one w dwóch typach spraw: zabójstwa dokonanego na ich terytorium oraz wspólnej ziemi. W odróżnieniu do Imperium Osmańskiego, w przeanalizowanych księgach nie znaleziono innych przypadków wspólnego działania lokalnych społeczności, przykładowo: przeciw skorumpowanemu chańskiemu urzędnikowi. Ostatnią, nieliczną, grupę klientów sądu stanowili niewolnicy, którzy brali udział w sprawach dotyczących ich wyzwolenia. Na przykład pewien Avs, syn Abdullaha, został przyprowadzony przed sąd kadiaskera przez chańskiego namiestnika (kethüda) z granicznej twierdzy Gazikerman położonej nad Dnieprem. Twierdził on, że przed kilkoma miesiącami Avs przeszedł na islam i został wyzwolony przez swojego ówczesnego pana. Jednak już kilka dni później złapano go w drodze do krajów niewiernych (dar-i harb), tj. Moskwy lub Rzeczypospolitej. Doprowadzony z powrotem do twierdzy, został sprzedany namiestnikowi. Najwyraźniej ponownie uznano go za niewiernego, a więc osobę która może stracić wolność. Avs jednak zakwestionował legalność tego aktu. Przed sądem kadiaskera przedstawił list wyzwoleńczy od poprzedniego pana na stepach i sąd ten potwierdził jego status wolnego człowieka ${ }^{17}$.

Zwraca uwagę fakt, że różny był stosunek poszczególnych grup społecznych pośród klientów sądu kadiaskera i sądu prowincjonalnego w Karasu. W tym ostatnim zwykli muzułmanie i nie-muzułmanie stanowili strony w aż 80-90\% spraw (zależnie od ich typów), a członkowie elit - jedynie w około $10 \%$. Powstaje pytanie o przyczyny tych różnic pomiędzy klientami obu typów sądów. Czy odzwierciedlały one różną strukturę społeczną w stolicy i na prowincji, czy też wskazują na odmienne postrzeganie obu typów sądów przez społeczeństwo Chanatu? Być może różnice wynikają ze splotu obu czynników.

Należy podkreślić, że w obu sądach zwykli poddani stanowili większość uczestników postępowania, a odsetek spraw z udziałem członków elit był znacznie mniejszy. Powyższa obserwacja jest zgodna ze zdroworozsądkową oceną proporcji pomiędzy poszczególnymi grupami społecznymi. Podobnie

${ }^{17}$ ORRNB, Fond 917, defter 23a/210b/5. 
należy się spodziewać większej liczby członków elity w stolicy - Bachczysaraju niż w prowincjonalnym Karasu. Niemniej jest również jasne, że nie istniało proste przełożenie pomiędzy odsetkiem członków danej grupy w społeczeństwie a odsetkiem spraw, w których występowali w sądach. Z pewnością ustalenie proporcji spraw sądowych z udziałem przedstawicieli danej grupy społecznej nie dostarczy dokładnych danych na temat ich udziału w społeczeństwie. Różnice pomiędzy pochodzeniem społecznym klientów obu typów sądów mogą także wskazywać, że służyły one do rozwiązywania trochę innych sporów. Wyższa liczba spraw z udziałem członków elit rozstrzygana w sądzie kadiaskera mogła wynikać z faktu, że uważano, iż ludzi o wyższym statusie winien sądzić najwyższy sędzia. Należy zwrócić uwagę, że największa różnica dotyczy spraw z udziałem szlachty. W sądzie kadiaskera stanowili oni $6,6 \%$ powodów, $8,9 \%$ oskarżonych i $13,0 \%$ stron kontraktów, podczas gdy w Karasu w żadnej kategorii nie przekroczyli oni 2,0\%. Te dane mogą wskazywać, że zarówno szlachta jak i jej sądowi przeciwnicy uważali sąd kadiaskera za bardziej odpowiednie forum do rozstrzygania spraw z jej udziałem.

Prostego wyjaśnienia dostarczył Charles Peysonnel, francuski konsul w Chanacie w drugiej połowie XVIII wieku. Według niego szlachta miała prawo być sądzona tylko przez kadiaskera ${ }^{18}$. W jego ujęciu krymscy mirzowie cieszyliby się przywilejem przypominającym ius non responsivum. Wpisy do ksiąg sądowym wskazują jedynie, że szlachta znacznie częściej występowała przed sądem kadiaskera niż przed sądami prowincjonalnymi. W księgach z tych ostatnich sądów znajdują się także sprawy z powództwa szlachty lub przeciw niej, co wskazuje, że nie-szlachcic mógł pozwać szlachcica przed prowincjonalnego kadiego ${ }^{19}$. Fakt, że zwykli poddani często woleli szukać sprawiedliwości u kadiaskera w sprawach przeciw szlachcie mógł być wynikiem ich własnych decyzji. Wydaje się, że u ich podstaw mogła leżeć chęć uniknięcia wpływów dobrze urodzonych przeciwników na lokalnego sędziego względnie - brak wiary w możliwości egzekucji wyroku na miejscowej szlachcie przez lokalny sąd. Niestety dostępne źródła nie dostarczają żadnych informacji na ten temat.

2. Kobiety i mężczyźni przed sądami chańskimi. Przed oboma typami sądów w podobnych proporcjach pojawiali się mężczyźni i kobiety. Dane zaczerpnięte z krymskich ksiąg sądowych ukazują muzułmańskie i nie-muzułmańskie poddane chana $\mathrm{w}$ różnorodnych rolach i jako wykonawczynie wielu czynności. Kobiety dysponowały majątkiem oddzielnym od swoich mężów, sprzedawały i kupowały nieruchomości, rozwodziły się z mężami, walczyły

${ }^{18}$ C. Peysonnel, Traité sur le commerce de la mer noire. Par M. De Peyssonel, ancien Consul General de France a Smirne, Associé des Academies de Marseille, de Lyon et Dijon; Membre Honoraire de celle des Antiquites de Cassel, et Correspondant de l'Academie Royale des Inscriptions et Belles-Letteres de Paris, t. 2, Paris 1787, s. 290.

${ }^{19}$ Por. ORRNB, defter 22/7a/2. 
o opiekę nad dziećmi, a także pozywały inne kobiety i mężczyzn we wszystkich typach spraw. Ich wizerunek wyłaniający się ze źródeł sądowych z pewnością jest daleki od tradycyjnego obrazu kobiet muzułmańskich podporządkowanych swoich mężom lub męskim krewnym ${ }^{20}$. Niemniej, wpisy pokazują również, że w Chanacie respektowano nakazy szariatu, ograniczające kobietom możliwości występowania w sądzie w roli świadków czy biegłych sądowych $^{21}$. Ponadto analiza statystyczna wpisów wskazuje, że znacznie rzadziej od mężczyzn występowały one przed sądem (patrz: Tab. 3 i 4) ${ }^{22}$. Widać również, że kobiety znacznie częściej bywały stroną w sprawach niespornych niż w sprawach spornych. W odniesieniu do tych ostatnich warto jednak zauważyć, że w obu sądach było stosunkowo więcej kobiet wśród powódek niż pozwanych. Najwyraźniej kobiety mogły i korzystały z możliwości ochrony swoich praw przed sądem.

Tabela 3. Płeć stron w sprawach przed sądem kadiaskera

\begin{tabular}{|c|c|c|c|}
\hline \multirow[t]{2}{*}{ Pleć } & \multicolumn{2}{|c|}{ Sprawy sporne (w \%) } & \multirow{2}{*}{$\begin{array}{c}\text { Sprawy niesporne } \\
(\mathbf{w} \%)\end{array}$} \\
\hline & Powodowie & Oskarżeni/pozwani & \\
\hline Mężczyźni & 83,6 & 91,0 & 70,0 \\
\hline Kobiety & 16,4 & 9,0 & 30,0 \\
\hline
\end{tabular}

${ }^{20}$ Adam Moniuszko przedstawił bardzo ciekawy materiał źródłowy ukazujący praktykę prawną w odniesieniu do Tatarek w Wielkim Księstwie Litewskim, żyjących przecież w otoczeniu chrześcijańskim. Pozwala on zauważyć istotne podobieństwa pomiędzy sytuacją kobiet muzułmańskich na Litwie i w Chanacie Krymskim oraz Imperium Osmańskim. Na tych terytoriach cieszyły się one prawem występowania przed sądem w różnych typach spraw majątkowych czy rodzinnych, włączając w to rozwód. Warto także zwrócić uwagę, że Tatarzy Litewscy rzadko żyli w związkach poligamicznych. Dane cytowane na ten temat przez Moniuszkę przypominają dane statystyczne oparte na osmańskich księgach sądowych z epoki wczesnonowożytnej, zob. A. Moniuszko, Changes in the Legal Culture of Lithuanian Tatars from the Sixteenth to the Eighteenth Century, [w:] Crossing Legal Culture, ed. L.B. Varela, P.G. Vega, A. Spinosa, München 2009, s. 187-201; M. Akif Aydın, Eyüp Şeriye Sicillerinden 184., 185 ve 188 No'lu Defterlerin Hukuki Tahlili, [w:] 18. Yüzyıl Kadı Sicilleri Işı̆̆ı̆nda Eyüp'te Sosyal Yaşam, ed. T. Artan, İstanbul 1999, s. 68; H. Gerber, Social and Economic Position of Women in the Ottoman City, Bursa, 1600-1700, „International Journal of Middle East Studies" 12 (1980), s. 231-244.

${ }^{21}$ R. Shaham, The Expert Witness in Islamic Courts. Medicine and Crafts in the Service of Law, Chicago-London 2010, s. 83-98.

${ }^{22}$ Statystyki uzyskane dla Chanatu przypominają te dotyczące obecności kobiet w sądach w Imperium Osmańskim w XVII wieku. Dla porównania można przywołać rezultaty badań dla trzech miast anatolijskich. Według Boğaça Ergene w Çankırı kobiety stanowiły 18\% powodów i 14\% oskarżonych, a w Kastamonu odpowiednio 27\% i 17\%, patrz: idem, Local Court, Provincial Society and Justice in the Ottoman Empire. Legal Practice and Dispute Resolution in Çankiri and Kastamonu (1652-1744), Leiden-Boston 2003, s. 115. Dla Kayseri Ronald Jennings podał, że kobiety stanowiły stronę w 17\% ogółu wszystkich spraw, idem, Women in the Early $17^{\text {th }}$-Century Ottoman Judicial Records: The Shari'a Court of Anatolian Kayseri, „Journal of the Economic and Social History of the Orient" 18 (1975), s. 66. 
Tabela 4. Płeć stron w sprawach przed sądem w Karasu

\begin{tabular}{|c|c|c|c|}
\hline \multirow[t]{2}{*}{ Pleć } & \multicolumn{2}{|c|}{ Sprawy sporne (w \%) } & \multirow{2}{*}{$\begin{array}{c}\text { Sprawy niesporne } \\
(\mathrm{w} \%)\end{array}$} \\
\hline & Powodowie & Oskarżeni/pozwani & \\
\hline Mężczyźni & 83,4 & 92,3 & 77,8 \\
\hline Kobiety & 16,6 & 7,7 & 22,2 \\
\hline
\end{tabular}

3. Miejsce zamieszkania. Różnice pomiędzy sądem kadiaskera i sądem prowincjonalnym widać także podczas analizy miejsca zamieszkania uczestników postępowania. W obu przypadkach większość spraw dotyczy - jak się wydaje - mieszkańców terenów położonych w niewielkiej odległości od sądu (do 20-30 km). O ile jednak do kadiego Karasu odwoływali się poza tym jedynie mieszkańcy sąsiednich okręgów, o tyle do sądu kadiaskera zwracali się mieszkańcy z całego Chanatu, a także z osmańskiej części Krymu. Te dane wyraźnie wskazują, że sąd kadiaskera miał znacznie większy autorytet i wpływy niż sąd prowincjonalny. Niemniej, należy zauważyć, że liczba spraw z udziałem mieszkańców innych okręgów niż Bachczysaraj jest ograniczona. Najwyraźniej chańscy poddani z prowincji rzadko - w przeciwieństwie do mieszkańców Bachczysaraju i okolic - decydowali się na wnoszenie spraw do sądu w stolicy. Ci ostatni nawet w najbardziej błahych kwestiach udawali się do najwyższego sędziego, co wskazuje, że żadna kategoria spraw nie została uznana za zbyt mało ważną dla kadiaskera. Najwyraźniej mieszkańcy prowincji w większości przypadków rozwiązywali problemy przed lokalnym sądem.

Jedynym wyjątkiem - jak się wydaje - były konflikty pomiędzy mieszkańcami dwóch różnych okręgów. Stanowią one $20 \%$ spraw wpisanych do ksiąg kadiaskerskich. Można przypuszczać, że powodowie mogli zdecydować się na przeniesienie procesu do stolicy z obawy, że układ sił w okręgu przeciwnika procesowego niekorzystnie wpłynie na wynik sprawy. W takiej sytuacji bardziej opłacalne mogło być poniesienie kosztów dojazdu do Bachczysaraju niż przegranie procesu w lokalnym sądzie. Powyższa hipoteza rzuca cień na niezawisłość krymskich kadich i na ich relacje z lokalnymi społecznościami. Należy wziąć pod uwagę możliwość, że wysoki odsetek spraw pomiędzy stronami z różnych stron półwyspu mógł wynikać po prostu z faktu, że stolica była ważnym centrum społecznym i ekonomicznym, a przez to miejscem spotkań poddanych z całego terytorium państwa.

Dane o miejscu zamieszkania klientów sądów chańskich przybliżają nas także do odpowiedzi na pytanie o zakres władzy chana w stosunku do mieszkańców bejlików wielkich rodów. W czasie panowania Murata Gireja zapisano czternaście spraw z ich udziałem w księgach kadiaskerskich i osiem w księdze z Karasu. Szesnaście spraw dotyczyło kwestii finansowych, dwie oskarżeń o spowodowanie uszczerbku na zdrowiu, a po jednej: rozwodu, kon- 
fliktu o prawo patronatu nad meczetem oraz wyzwolenia niewolnika. Wydaje się, że mieszkańcy bejlików korzystali z sądów chańskich w podobny sposób jak inni poddani chańscy mieszkający w pewnej odległości od sądu ${ }^{23}$.

\section{Sprawy rozstrzygane przez sądy - analiza typów spraw oraz stra- tegii obieranych przez strony.}

1. Typy spraw. Przed oboma typami sądów zarówno spory jak i kontrakty dotyczyły głównie kwestii finansowych. Drugą najważniejszą grupę stanowiły wpisy testamentów i rozliczenia podziałów spadków, które także można zaliczyć do spraw finansowych. Inne problemy, jak - na przykład - sprawy rodzinne, oskarżenia o zabójstwo i o uszczerbek na zdrowiu, wyzwolenia oraz kwestie organizacyjne dotyczące fundacji religijnych spotyka się znacznie rzadziej (patrz Tab. 5).

Tabela 5. Typy spraw przed sądem kadiaskera i sądem prowincjonalnym w Kara $\mathrm{Su}$

\begin{tabular}{l|c|c}
\hline \multicolumn{1}{c|}{ Typ sprawy } & $\begin{array}{c}\text { Sąd } \text { kadiaskera } \\
\mathbf{( w} \text { \%) }\end{array}$ & $\begin{array}{c}\text { Sąd } \\
\text { prowincjonalny } \\
\text { w Kara Su } \\
\text { (w \%) }\end{array}$ \\
\hline $\begin{array}{l}\text { Kontrakty kupna-sprzedaży oraz ustanowienie } \\
\text { pełnomocnictwa }\end{array}$ & 27 & 26 \\
\hline Spory majątkowe & 34 & 43 \\
\hline Sprawy rodzinne & 9 & 5 \\
\hline Spadki & 10 & 12 \\
\hline Zabójstwa, morderstwa, gwałty i uszkodzenia ciała & 7 & 6 \\
\hline Kradzieże i zabór mienia & 2 & 2 \\
\hline Sprawy fundacji religijnych (wakfów) & 1 & 2 \\
\hline Wyzwolenia & 6 & 3 \\
\hline Wpisy administracyjne & 3 & 1 \\
\hline
\end{tabular}

Należy zwrócić uwagę na pewne różnice pomiędzy prawem muzułmańskim i europejskim w kwestii podziału na sprawy ścigane $\mathrm{z}$ oskarżenia prywatnego i publicznego. W Chanacie - na przykład - sprawy o zabójstwo i uszczerbek na zdrowiu podlegały oskarżeniu prywatnemu poszkodowanego lub jego najbliższych krewnych, podczas gdy urzędnicy chańscy byli zobowiązani do doprowadzenia przed sąd tylko tych, którzy popełniali przestępstwa koraniczne takie, jak: kradzież, picie alkoholu, odbywanie nielegalnych

\footnotetext{
${ }^{23}$ N. Królikowska, Law and Division of Power in the Crimean Khanate, s. 179.
} 
stosunków seksualnych, oskarżenie o takowe oraz rabunek na drodze publicz$n^{j^{24}}$. Te przestępstwa podlegały - w teorii - surowym karom, np. odcięciu ręki złodziejowi. Wydaje się, że chan, za przykładem sułtana osmańskiego zamieniał je na lżejsze, jak chłosta czy grzywna ${ }^{25}$.

Pewne zdziwienie może także budzić fakt, że kradzież, która w wielu społeczeństwach należy do przestępstw najbardziej powszechnych, w Chanacie była zgłaszana do sądu stosunkowo rzadko. Prawo muzułmańskie rozróżnia dwa główne typy tego przestępstwa: kradzież zdefiniowaną jako przestępstwo koraniczne (sarika) i bezprawne zabranie czyjejś własności $(\text { gasp })^{26}$. W przypadku kradzieży zdefiniowanej w Koranie, której popełnienie było zagrożone wysoką karą ucięcia ręki, można tłumaczyć rzadkie wzmianki w księgach sądowych jej bardzo wąską definicją w prawie islamskim oraz trudnymi do spełnienia wymogami dowodowymi. Rudolph Peters wyliczył, że aby czyn mógł zostać uznany za kradzież, musiały wystąpić następujące okoliczności:

1. rzecz musiała być zabrana ukradkiem;

2. rzecz musiała mieć pewną określoną wartość minimalną;

3. złodziej nie mógł być jej współwłaścicielem;

4. rzecz nie mogła być mu w jakikolwiek sposób powierzona, np. jako sprzedawcy w sklepie patrona;

5. rzecz musiała być skradziona z zamkniętego lub dobrze strzeżonego miejsca $^{27}$.

Ponadto każda ze szkół prawnych dodawała własne ograniczenia. Szkoła hanaficka, uznana za główną w chanacie, definiowała na przykład minimalną wartość rzeczy dość wysoko, bo na równowartość 29,7 gramów srebra, i uznawała, że kradzież nie obejmuje jedzenia. Następnie prawnicy hanaficcy uważali, że jeśli złodziej oddałby ukradzioną rzecz przed wydaniem wyroku, to należy go uniewinnić. Te wszystkie obostrzenia sprawiały, że istotnie - trudno było skazać kogoś skutecznie za kradzież. Przypuszczalnie z tych względów niezwykle rzadko w krymskich księgach sądowych zapisywano takie oskarżenia. Powyższe restrykcje nie obowiązywały w kwestii oskarżeń

${ }^{24}$ ORRNB, Fond 917, defter 25/116a/5.

${ }^{25}$ Ibidem, defter $25 / 31 \mathrm{a} / 3 ; 25 / 48 \mathrm{a} / 4$.

${ }^{26}$ Teoretycy prawa muzułmańskiego uznawali, że zabór mienia nie spełniający wymogów przestępstwa koranicznego skutkuje grzechem i długiem. Kładziono nacisk głównie na zwrot zagrabionego mienia lub jego wartości. Władcy muzułmańscy, np. sułtan osmański, nakazywali w tych przypadkach stosowanie łagodniejszych kar, np. chłosty, niż przepisane w prawie muzułmańskim kary mutylacyjne dla kradzieży zdefiniowanej koranicznie. Co ciekawe, praktyka sądu osmańskich wskazuje, że te łagodniejsze kary miały zastosowanie także, gdy czyn kwalifikował się jako przestępstwo koraniczne, co w przypadku Imperium Osmańskiego tłumaczy się praktycznym nastawieniem tamtejszego wymiaru sprawiedliwości, zob. U. Heyd, Studies in Old Ottoman Law, Oxford 1973, s. 111-112, 264-265; C. Imber, Ebu's-su ud. The Islamic Legal Tradition, Edinburgh 1997, s. 213-220.

${ }^{27}$ R. Peters, Crime and Punishment in Islamic Law. Theory and Practice from the Sixteenth to the Twenty-first Century, Cambridge 2005, s. 56. 
o bezprawne zabranie czyjejś własności (gasp). Stąd w krymskich księgach sądowych znacznie częściej znajduje się sprawy, w których wysuwano to oskarżenie. Co więcej, na podstawie XVIII-wiecznych źródeł narracyjnych można stwierdzić, że w Chanacie w kwestii kradzieży stosowano elementy prawa stanowionego przez władcę i sprzecznego z prawem szariatu. Znane, niestety jedynie ze źródeł narracyjnych, rozwiązania wydają się wzorowane na praktyce osmańskiej ${ }^{28}$. Liczba oskarżeń o bezprawny zabór własności w porównaniu do ogółu spraw wpisanych do ksiąg pozostaje zastanawiająco niska. Stosunkowo rzadko znajduje się w księgach sądowych sprawy o zabójstwo lub uszczerbek na zdrowiu. Czy rzeczywiście, tak jak - wiek wcześniej - chciał Michalon Litwin, chańscy poddani rzadko popełniali te przestępstwa, czy też rozwiązywali te sprawy na innych forach niż sądy szariackie - choćby sądach starszych rodu czy na drodze zemsty rodowej ${ }^{29}$. Zachowane źródła nie pozwalają na jednoznaczne rozstrzygnięcie tej wątpliwości. W przypadku tylko jednej grupy społecznej, tj. członków rodów karaczych, źródła zawierają pewne przesłanki sugerujące istnienie i działanie instytucji sądowniczej innej niż sądy chańskie. Zwraca uwagę także fakt, że w księgach sądowych brak wpisów odnoszących się do członków rodów karaczych w sprawach kryminalnych i konfliktach rodzinnych. Najwidoczniej te sprawy musiały być rozwiązywane w inny sposób, być może - właśnie przed sądem starszych rodu.

2. Strategie obierane przez strony. W jaki sposób wygrać sprawę? Jaki typ dowodów będzie najbardziej przekonywający dla sędziego? Te pytania musiały stawiać sobie strony w procesach przed sądami chańskimi. Tab. 6 przedstawia ich strategie postępowania oraz typy dowodów.

Na wstępie należy zauważyć, że w jednej sprawie strony mogły wykorzystać kilka środków dowodowych. Zwraca uwagę, że w obu typach sądów wykorzystywano różne strategie w podobnych proporcjach. Najpopularniejszym środkiem dowodowym były zeznania świadków, co wynikało najprawdopodobniej z dwóch przyczyn; po pierwsze - prawo muzułmańskie uważało zeznania przynajmniej dwóch świadków za najbardziej wiarygodny środek dowodowy, a po drugie - był to stosunkowo łatwy sposób potwierdzenia swojej wersji wydarzeń. Był on popularny w wielu społeczeństwach nowożytnych. Prawo muzułmańskie nakazywało, że świadek musiał być prawym i wolnym muzułmaninem. Nawet muzułmanki o nieposzlakowanej opinii miały ograniczone prawa do występowania w tej roli w sądzie. Pomimo że

${ }^{28}$ N. Kleemann, Voyage de Vienne à Belgrade et à Kilianova, Dans le pays des Tartares Budziacs et Nogais dans la Crimée, et Kaffa à Constantinople; que travers de la mer Noire; avec le retour à Vienne; par Trieste. Fait dans les années 1768, 1769 et 1770, par Nicolas-Ernest Kleemann. On y a joint description des choses les plus remarquables concernant la Crimée, Neuchâtel 1780, s. 90-109.

${ }^{29}$ F. Laškov, Istoričeskij očerk krymsko-tatarskogo zemlevladenija, część 2 - ITUAK 23 (1896), s. 87. 
Tabela 6. Strategie obierane przez strony sporów

\begin{tabular}{l|c|c}
\hline \multicolumn{1}{c|}{ Typ strategii } & $\begin{array}{c}\text { Sąd } \text { kadiaskera } \\
(\mathbf{w} \%)\end{array}$ & $\begin{array}{c}\text { Sąd prowincjonalny } \\
\text { w Kara Su (w \%) }\end{array}$ \\
\hline Zeznania świadków & 33 & 30 \\
\hline Ugoda & 15 & 14 \\
\hline Przyznanie się do winy & 27 & 28 \\
\hline Odrzucenie oskarżenia powoda & 1 & 0 \\
\hline i wysunięcie kontroskarżenia & 3 & 5 \\
\hline Przysięga powoda & 7 & 5 \\
\hline Przysięga oskarżonego & 4 & 2 \\
\hline Inne dowody & 2 & 3 \\
\hline Przedstawienie dokumentów & 8 & \\
\hline Brak dowodów & & 3 \\
\hline
\end{tabular}

świadkowie rekrutowali się spośród szanowanych członków społeczności, to przynajmniej w Chanacie narażeni byli na ataki strony przeciwnej. Można na przykład przywołać przykład pewnego nogajskiego mirzy, który tak skutecznie nastraszył świadków swojego sądowego oponenta, że ci odmówili publicznego składania zeznan ${ }^{30}$. W sądach w Chanacie strony udowadniały swoje racje, odwołując się również do innych środków, takich jak przyznanie się do winy oraz przysięgi obu stron. Były one także oparte na założeniu prawa muzułmańskiego, że najbardziej wiarygodny dowód stanowi słowo .

Niezwykle rzadko strony dowodziły swoich racji na podstawie dokumentów. W takich przypadkach korzystano z: przywilejów chanów i kałgów, odpisów spraw wpisanych wcześniej do ksiąg sądowych oraz opinii prawnych najwyższego muftiego Chanatu. Przedstawienie pierwszego typu dokumentu w każdej ze spraw stanowiło argument rozstrzygający na korzyść okazicie$\mathrm{la}^{31}$. Prawie równie skuteczne było przedstawienie wypisu z ksiąg ${ }^{32}$. W czasie panowania Murata Gireja tylko raz - przynajmniej w świetle przebadanego materiału - zakwestionowano ten typ dowodu. Oskarżony zwrócił się do sądu, by odrzucił dowód przedstawiony przez powoda - odpis wyroku wcześniej rozstrzygniętej sprawy, ponieważ sędzia wydał ów wyrok, opierając się na fałszywych zeznaniach świadków ${ }^{33}$. Warto zwrócić uwagę, że odpis wcześniejszego wyroku służył także oskarżonym jako kontrargument wobec powodów. Wskazuje to, że ci ostatni, uzyskawszy w jednym sądzie nieko-

\footnotetext{
${ }^{30}$ ORRNB, Fond 917, defter 23b/111b/1.

${ }^{31}$ Ibidem, defter 22/102a/6; 23a/228b/2.

${ }^{32}$ Ibidem, defter 22/99a/4; 22/98a/2; 22/88a/7.

${ }^{33}$ Ibidem, defter 23b/68b/2.
} 
rzystny dla siebie wyrok, wbrew zasadom prawa muzułmańskiego, które nie znało instytucji apelacji i uważało wyrok każdego sądu za ostateczny, szukali szczęścia przed kolejnym sędzią. Nie jest do końca jasne, w jakim stopniu strategią skuteczną było prezentowanie trzeciego typu dokumentów, tj. opinii prawnej muftiego (fetwy). Zasadniczo zgodnie z prawem muzułmańskim nie stanowiły one środka dowodowego, a sędzia nie był zobowiązany do wydania wyroku zgodnego z fetwą. Praktyka sądowa w Chanacie wskazuje, że rzeczywiście fetwa nie była traktowana jako dowód w sprawie. Nigdy nie stanowiła jedynego użytego argumentu. Niemniej wpisy wyraźnie wskazują, że opinie muftich cieszyły się dużym autorytetem. Strona zaś, która przytoczyła korzystną dla siebie fetwę, wygrywała sprawę ${ }^{34}$.

W księgach sądowych z czasu panowania Murata Gireja napotyka się także pojedyncze przypadki wykorzystania pomocniczych środków dowodowych dopuszczanych przez prawo muzułmańskie, tj. opinii biegłych ${ }^{35}$ oraz oględzin miejsca zbrodni ${ }^{36}$. Jedynie w źródłach narracyjnych znajdują się informacje, że sędziowie dopuszczali także jako dowód zeznania złożone w czasie tor$\operatorname{tur}^{37}$. O ile klasyczny islam uważał je za niedozwolony środek dowodowy, o tyle prawo stanowione w różnych nowożytnych państwach muzułmańskich, w tym w Imperium Osmańskim, uznawało ich ważnośćc ${ }^{38}$.

Przedstawione dane wskazują, że w wielu sprawach strony rezygnowały jednak z prowadzenia postępowania dowodowego w sądzie na rzecz ugody (15,0\% spraw w sądzie kadiaskera i 14,0\% w sądzie prowincjonalnym w Karasu). Tendencja do szukania rozwiązania możliwego do zaakceptowania przez obie strony stanowi jeden z elementów niezwykle charakterystycznych dla praktyki prawa w państwach muzułmańskich ${ }^{39}$. Wydaje się, że w Chanacie, podobnie jak w Imperium Osmańskim, kompromis bywał zwykle poprzedzony trudnymi i długimi negocjacjami, w których mediatorem mógł być sam sędzia lub jego podwładni. Wskazują na to imiona pracowników sądu na listach świadków sądu we wpisach poświadczających zawarcie ugody ${ }^{40}$.

${ }^{34}$ Ibidem, defter 22/22a/6.

${ }^{35}$ Jedyny przykład stanowi sprawa kobiety, która wystąpiła do sądu o powiększenie kwoty przeznaczonej na utrzymanie, którą wyznaczył jej mąż przed wyruszeniem na służbę w twierdzy Szachkerman. Sąd powołał biegłego, który stwierdził, że rzeczywiście pieniądze otrzymywane przez kobietę były niewystarczające, zob. ORRNB, Fond 917, defter 23b/23b/57a.

${ }^{36}$ Ibidem, defter 23a/221a/2; defter 23b/78a/1.

${ }^{37}$ N. Kleemann, Voyage de Vienne à Belgrade et à Kilianova, s. 90-109.

${ }^{38}$ U. Heyd, Studies in Old Ottoman Law, s. 106, 116, 118-119.

${ }^{39}$ L. Rosen, The Anthropology of Justice: Law as Culture in Islamic Society, Cambridge 1989, s. 26-66; B. Ergene, Local Court, Provincial Society and Justice in the Ottoman Empire, s. 189-207. Warto zauważyć, że także we wczesnonowożytnej Rzeczypospolitej spory rozwiązywano na drodze mediacji i przez sądy polubowne, zob. A. Rosner, Tradycja staropolskiego sądownictwa polubownego - próba zarysowania problemu, [w:] Sprawiedliwość naprawcza. Idea. Teoria. Praktyka, red. M. Płatek, M. Fajst, Warszawa 2005, s. 37-58.

${ }^{40}$ Patrz na przykład: ORRNB, Fond 917, defter 23b/91a/8; 23b/91b/1. 
Podsumowując: klienci sądów chańskich używali różnych strategii, by otrzymać satysfakcjonujący ich wyrok. W kwestii dowodów krymska praktyka była zgodna z klasyczną doktryną muzułmańską. Wyjątkiem mogła być jedynie kwestia dopuszczenia zeznań wymuszonych przez tortury. Nie budzi zdziwienia przywiązanie klientów sądów chańskich do świadectw ustnych, a także rzadkie wykorzystanie przez nich innych dowodów, takich jak dokumenty czy dowody zebrane na miejscu przestępstwa. Analiza wpisów wskazuje także, że powodowie przychodzili zazwyczaj dobrze przygotowani do procesu. Jedynie w nielicznych sprawach nie mogli przedstawić żadnych dowodów na swoją korzyść. Zapewne w takich przypadkach mogli być stroną dążącą do zawarcia ugody.

IV. Podsumowanie. Analiza praktyki sądów w czasie panowania Murata Gireja wskazuje, że chan zapewniał swoim poddanym dostęp do sądów i stał na straży przestrzegania prawa w chanacie. Jego władza sądownicza - jak się wydaje - była jednak ograniczona na terenach własności wielkich rodów oraz w stosunku do tej grupy społecznej. Ponadto istnieją poważne wątpliwości, czy rzeczywiście chan - jak chcieliby to widzieć pewni europejscy dyplomaci - panował nad państwem o wyróżniającym się bezstronnością systemie sprawiedliwości i nad nieskazitelnie praworządnymi poddanymi. Pewne elementy opisu systemu prawnego Chanatu, obecne choćby w dziele Michalona Litwina, odpowiadają jednak rzeczywistości. Sądownictwo działało sprawnie, a procesy odbywały się szybko. Brakowało skarg poddanych na skorumpowanych urzędników sądowych. Niemniej należy zauważyć, że w pewnych typach spraw, takich jak spory między stronami z różnych okręgów sądowych, czy też sprawy między szlachtą a zwykłymi poddanymi, strony preferowały sąd kadiaskera. Nie chciały zwracać się do lokalnego sędziego. Nie można wykluczyć, że jedną z przyczyn była obawa o stronniczość prowincjonalnego kadiego. Trudno także obronić tezę europejskich dyplomatów o niezwykłej praworządności samych Tatarów. W krymskich księgach sądowych niewielki odsetek wpisów dotyczy przestępstw i czynów o charakterze semikryminalnym, takich jak kradzież czy zabójstwo i dokonanie uszczerbku na zdrowiu. Porównanie z Imperium Osmańskim, jak i lektura narracyjnych i sądowych źródeł krymskich wskazuje jednak, że nieznaczny - wśród innych wpisów - udział tych typów spraw mógł mieć różne przyczyny. Niekoniecznie oznaczało to, że czyny te zdarzały się rzadko. Z pewnością bohaterowie poniższego wpisu w krymskich księgach sądowych nie byliby przykładem szacunku dla prawa dla europejskich poddanych:

Powód stwierdził: „Piliśmy i bawiliśmy się razem, gdy zaczęła się sprzeczka między Ahmedem i Mehmedem. Gdy ten pierwszy wyszedł na zewnątrz i dosiadł konia, ten drugi podążył za nim. Zobaczywszy go Ahmed wystrzelił z łuku i zabił go"41.

${ }^{41}$ Ibidem, defter 22/78v/1. 
Słowem: odnosi się wrażenie, że zarówno krymska Temida, jak i sami Tatarzy zasługiwali jedynie na część pochwał, którymi tak hojnie obdarzyli ich zagraniczni obserwatorzy.

\section{LAW-ABIDING AS A TATAR? LEGAL RELATIONS IN THE CRIMEAN KHANATE AS SEEN IN $17^{\text {TH}}$-CENTURY COURT REGISTERS}

\section{Summary}

The purpose of this paper is to outline the legal practice in the Crimean Khanate in the 17th century. This longest surviving Eastern European post-Genghis state is a very interesting case for any student of the history of political systems and law. This is because its law and state institutions were based on both Mongolian and Islamic-Ottoman models, producing a highly original system. The study is based on rich data surviving in Crimean court registers from the reign of Khan Murad Giray (1678-1683). Treating them as ancillary sources, it makes use of selected entries in other surviving Crimean court registers from 1608-1783 supplemented by information taken from other sources: Tatar, Ottoman and European.

The study attempts to find answers to the following questions: who, against whom and in what types of cases, appeared in a given type of court in the Khanate. Answering these questions reveals not only what everyday life of the Khan's subjects, coming from various social groups, looked like, but also what principles were followed by the Khanate's legal system and administration. The collected data shows that the Khan fulfilled the basic duty of any Muslim ruler and gave his subjects access to courts and ensured that law was obeyed. The Khanate was divided into judicial circuits (kazas) in which the highest-ranking official was a judge (kadi). Subjects could also approach the highest judge (cadiasker) about a matter that concerned them. However, there are reasons to believe that his judicial authority was restricted with respect to estates (beyliks) belonging to grand families (karachis) and when it came to this social group itself.

The sources also indicate that the Khan's judicial authority was restricted in lands supervised by a kalga - the first deputy of the Khan chosen from among the members of the ruling dynasty. The study of the cases entered in the registers of a $c a$ diasker court and the registers of a provincial court in Kara Su during the reign of Murad Giray, shows that the clients of the Khan's justice were members of all social groups, men and women, Muslims and non-Muslims. The frequency in which people appeared in court and the types of cases they litigated, differed slightly depending on their social background, sex and religion. The paper attempts to explain these differences by carefully analysing the social background of parties, their place of residence, sex, types of cases and litigation strategies. 


\section{RESPECTER LES LOIS COMME UN TATAR? \\ LES RAPPORTS JURIDIQUES DANS LE KHANAT DE CRIMÉE SUR LA BASE DES REGISTRES DES TRIBUNAUX LOCAUX DU XVIIE SIÈCLE}

\section{Résumé}

Le but de l'article est de faire une esquisse de la pratique juridique dans le Khanat de Crimée au XVII ${ }^{\mathrm{e}}$ siècle. Cet État d'Europe orientale post Gengis Khan, ayant existé le plus longtemps, est un cas fort intéressant pour un chercheur dans l'histoire du régime et du droit. Le droit et les institutions publiques du Khanat sont basés sur les modèles tant mongoles qu'islamo-ottomans, créant ainsi un système original. La source de base est une riche documentation issue des registres de tribunaux de Crimée de l'époque du khan Murad Giray (1678-1683) ainsi que des inscriptions sélectionnées dans d'autres registres, conservés par les tribunaux de Crimée dans les années 1608-1783, la documentation ayant été complétée des faits en provenance d'autres sources telles que tatares, ottomanes et européennes. L'article tâche également de répondre à la question suivante: qui, contre qui, et dans quelles affaires, intervenait-il devant les tribunaux particuliers du Khanat? L'analyse de ces questions permet de nous rapprocher non seulement de la vie quotidienne des sujets du Khan provenant de différents groupes sociaux mais également des principes de fonctionnement du système juridique et de l'administration du Khanat. La documentation réunie confirme en outre que le khan respectait son obligation principale du souverain musulman et qu'il assurait à ses sujets l'accessibilité des tribunaux. Par ailleurs, c'est lui qui veillait sur le respect de la loi. Le Khanat est divisé en arrondissements juridictionnels, kazas, dans lesquels le magistrat suprême est un juge, cadi. Les sujets pouvaient par ailleurs présenter leurs dossiers au juge suprême, cadiasker. Néanmoins, il existe des motifs qui nous permettent de constater que le pouvoir juridictionnel de ce dernier était limité dans les provinces gouvernées par le bey, beyliks de grands clans, dits qarachis et par rapport à ce groupe social. Les sources démontrent également l'existence des limites du pouvoir juridictionnel du khan sur les territoires dépendant de qalga - le premier adjoint au khan, désigné parmi les membres de la dynastie régnante. L'analyse des dossiers inscrits aux registres du tribunal du cadiasker ainsi que celle des registres du tribunal de province de Karu Su, sous le règne de Murad Giray, prouve que les clients de la justice du khanat étaient membres de tous les groupes sociaux, femmes et hommes, musulmans et non musulmans. Nous pouvons nous apercevoir de certaines différences en fonction de l'origine sociale, du sexe et de la confession, au niveau de la « fréquentation » du tribunal par le client et du type d'affaires dans lesquelles les parties comparaissaient.

Dans le présent article est donc décrite une tentative d'expliquer les différences susvisées sur la base d'une analyse détaillée de l'origine sociale des parties, du domicile, du sexe, du type de dossiers et des stratégies adoptées au tribunal. 